\title{
RAMAN SPECTRA AND INTERMOLECULAR HYDROGEN BONDS OF QUINOLINE IN SOLUTIONS
}

\author{
F.H. TUKHVATULlin, A. JUMABAEV, H. HUSHVAKTOV, A. ABSANOV, \\ B. HUDOYBERDIEV
}

PACS 78.30.Cd, 82.30.Rs (C) 2012
Samarkand State University

(15, University Blvd., 140104 Samarkand, Uzbekistan; e-mail: ahmad@ samdu. uz)
The half-widths of the 1014- and $1033-\mathrm{cm}^{-1}$ bands of the Raman spectrum of quinoline at its dilution in neutral solvents (benzene, $\mathrm{CCl}_{4}$ ) are narrowed by 1.3-1.5 times at high dilutions. This effect is associated with the increased time of the vibrational relaxation. For the $520-\mathrm{cm}^{-1}$ band in pure liquid quinoline, the parallel polarized component at $20^{\circ} \mathrm{C}$ is asymmetric in the highfrequency region. The shape of the perpendicular polarized component is complicated. A non-coincidence of the peak frequencies of the parallel and perpendicular polarized components is observed $\left(\sim 2 \mathrm{~cm}^{-1}\right)$. Quantum-chemical calculations showed that, in the region of $520 \mathrm{~cm}^{-1}$ for a monomer molecule, we should really have two near located lines with the wavenumbers 530 and $527 \mathrm{~cm}^{-1}$ (scaling factor 0.97), and with the depolarization ratios 0.61 and 0.26 . In the solutions with propan-2-ol, the $1033.8-\mathrm{cm}^{-1}$ band becomes of a doublet character. The resolution of the doublet becomes better by the dilution of a binary quinoline-alcohol solution with a large amount of a neutral solvent (benzene). The wavenumbers of bands in the triple mixture are $1033 \mathrm{~cm}^{-1}$ and $1039 \mathrm{~cm}^{-1}$. The doublet nature of the band in the binary and triple mixtures is associated with the presence of monomer molecules and quinoline-propan-2-ol aggregates (the high-frequency line) in the liquid mixture. Quantum-chemical calculations showed that the hydrogen bonds with a length of $1.958 \AA$ and an energy gain of $22.0 \mathrm{~kJ} /$ mole can be formed between molecules of quinoline and alcohol. The formation of aggregates can be also detected in the $820-\mathrm{cm}^{-1}$ band of propan-2-ol. A similar picture is observed for the $667-\mathrm{cm}^{-1}$ band of chloroform in its solution with quinoline.

\section{Introduction}

A significant attention is paid currently to the investigation of intermolecular and intramolecular hydrogen bonding in compounds. This is conditioned by the necessity of a better understanding of the structure of liquids and solids, as well as by the importance of such investigations for understanding the processes in biological systems [1-19]. The detailed information about the hydrogen bonding is a key to understanding the structure and properties of liquid water [20], alcohols [21-24], proteins, and DNA [1]. Studies of properties of hydrogen bonds involve various methods [2, 25-27]. Particularly fruitful ones are based on the molecular spectroscopy. It may be said that the basic information about the hydrogen bonding was obtained on the base of the study of molecular spectra. The basic information about the manifestation of the hydrogen bonding in molecular spectra is presented in [2]. Intermolecular hydrogen bonds of nitrogen-containing molecules possess some peculiar features.

The formation of intermolecular hydrogen bonds involving a nitrogen atom of nitrogen-containing molecules usually results in the appearance of a band associated with aggregates in the spectra of Raman scattering (RS) in the high-frequency side of the band of molecular vibrations, in which this nitrogen atom participates [2830]. In [31], it has been suggested that this is associated with the participation of $\sigma$-electrons of the nitrogen atom in the hydrogen bonding and the strengthening of the $\pi$-bond of this atom with other atoms in the molecule. If the aggregation occurs with the participation of $\pi$-electrons of nitrogen, then, as in the case of the aggregation of molecules of acetonitrile [31], the band of aggregates appears in the low-frequency side. Among the nitrogen-containing molecules, there is a molecule of quinoline. In works [32-34], a possibility for quinoline and its derivatives to participate in the formation of intermolecular H-bonds with proton-donor molecules was shown. As in the case of pyridine and acetonitrile solutions with proton-donor substances, the band of aggregates of quinoline for vibrations with the participation of nitrogen atoms appears in the high-frequency side. This result was obtained for the $1034.8-\mathrm{cm}^{-1}$ band in the Raman spectra of quinoline in a solution with propan2-ol. However, not all the details of the manifestation of molecular aggregations of quinoline in Raman spectra have been clarified. It is necessary to investigate the Raman spectrum of quinoline with other solvents, which will give more opportunities to interpret the spectra. A significant help in interpreting the results may come from quantum-chemical calculations. In this regard, we have decided to continue the study of the Raman spectra of quinoline in solutions with neutral and proton-donor solvents, among which heptane, $\mathrm{CCl}_{4}$, chloroform, and 
propan-2-ol were selected. A specific attention was paid to the 520 - and $1034.8-\mathrm{cm}^{-1}$ bands of quinoline. We also studied the $667-\mathrm{cm}^{-1}$ band of chloroform. In a solution with the proton-acceptor solvents, this band is split into two bands.

\section{Experimental Technique and Method of Quantum-Chemical Calculations}

Raman spectra were recorded with the help of an automated spectrometer DFS-52, which is a double monochromator with two gratings 1800 lines $/ \mathrm{mm}$. The excitation source was an argon laser LGN-503 with a wavelength of $488 \mathrm{~nm}$ and the output power of $1 \mathrm{~W}$. All measurements were performed at the $90^{\circ}$-geometry of scattering for the polarized exciting light. Accounting for the instrumental distortions, if necessary, was performed by the method described in [35]. The measurements were made at a temperature of $20^{\circ} \mathrm{C}$. In the experiment, we used a chemically pure substance, which was subjected to the additional distillation under vacuum. Errors in the determination of the bandwidth and in the relative position of the bands were $\pm 0.3 \mathrm{~cm}^{-1}$.

Quantum-chemical calculations were carried out in the B3LYP (DFT) approximation with a set of the Gauss functions 6-31G ${ }^{++}(\mathrm{d}, \mathrm{p})[36]$ for isolated monomer molecules of quinoline and for a dimeric quinolinepropan-2-ol aggregate.

\section{Results of Experimental Studies and Calculations}

First of all, we discuss the results of the experiment. Figure 1 (curves 1 and 2) presents the spectra of parallel $\left(I_{\|}(\nu)\right)$ and perpendicular $\left(I_{\perp}(\nu)\right)$ polarized components of the Raman band of quinoline at $520 \mathrm{~cm}^{-1}$. It is seen that the shapes of the $I_{\|}(\nu)$ and $I_{\perp}(\nu)$ contours for this band are strongly different. The parallel polarized component is asymmetric on the high-frequency side, where a band of aggregates usually appears. The $I_{\perp}(\nu)$ component is of a special kind, namely, the kind that usually corresponds to the band consisting of two overlapping lines with approximately equal intensity. If so, then this means that the depolarization ratios of these overlapping lines are different. The ratio is greater for the line with higher frequency. Because of the small value of the depolarization ratio of the low-frequency band in the $I_{\|}(\nu)$ component, the low-frequency band dominates by the intensity, and it determines the maximum frequency of the resultant band. In $I_{\perp}(\nu)$ (the anisotropic component) due to a small value of the depolarization ratio of the low-frequency line, the components of the line shape of the band lines are approximately equal by the intensity, which leads, in our view, to a special form of the $I_{\perp}(\nu)$ band. In such cases, a non-coincidence of frequencies of $I_{\|}(\nu)$ and $I_{\perp}(\nu)$ is usually observed. In our case, it is difficult to determine this difference because of the special shape of the band $I_{\perp}(\nu)$. Approximate calculations give the magnitude of $2 \mathrm{~cm}^{-1}$ for the difference of frequencies of the maxima. Quantumchemical calculations have shown that, in the region of $520 \mathrm{~cm}^{-1}$, we must have, indeed, two closely spaced lines for monomer molecules with wavenumbers, respectively, $530 \mathrm{~cm}^{-1}$ and $527 \mathrm{~cm}^{-1}$ (the exact correspondence of calculated and experimental values of the wavenumbers is not reached by the method used for calculations). According to calculations, both bands correspond to planar vibrations of molecules and are not characteristic. Because of the small difference in the wavenumbers of lines, they are not resolved as two lines by our experimental apparatus. Apparently, due to differences in the values of depolarization ratio of the components (lines) of the band (calculations give 0.61 and 0.26 , respectively), we have a special form of the resulting bands $I_{\|}(\nu)$ and $I_{\perp}(\nu)$.

In our paper [31], we suggested that the cause for the discrepancy in peak frequencies of some bands in the scattered light of different polarizations in the Raman spectra of liquid substances is partly due to the complexity of the bands, i.e. the superposition of closely spaced lines with different depolarization ratios, which belong to different aggregations of molecules of substances. Due to the small differences in the frequencies, the lines are not resolved by experimental apparatus. But, because of the different polarization ratios of lines, the positions of peaks of the same bands are different in the spectra of scattered light of different polarizations. In the case of the $520-\mathrm{cm}^{-1}$ band of quinoline, we deal with the overlapping of lines of different polarizations, referred to intramolecular vibrations. Thus, the overlapping of bands is independent of the aggregation of molecules, but the result appeared to be the same: the overlapping of two closely spaced bands with different depolarization ratios leads to a peculiar form of the bands in two polarizations of the scattered light with the non-coincidence of peak frequencies. In the case of the complicated $520-\mathrm{cm}^{-1}$ band, the difference between the peak frequencies is, as mentioned above, approximately $2 \mathrm{~cm}^{-1}$. Thus, the idea stated in [31] is rather reasonable. We should note that, in the literature, the problem of non-coincidence of peak frequencies of bands of the same vibrations in different polarizations of the scattered light has been discussing 


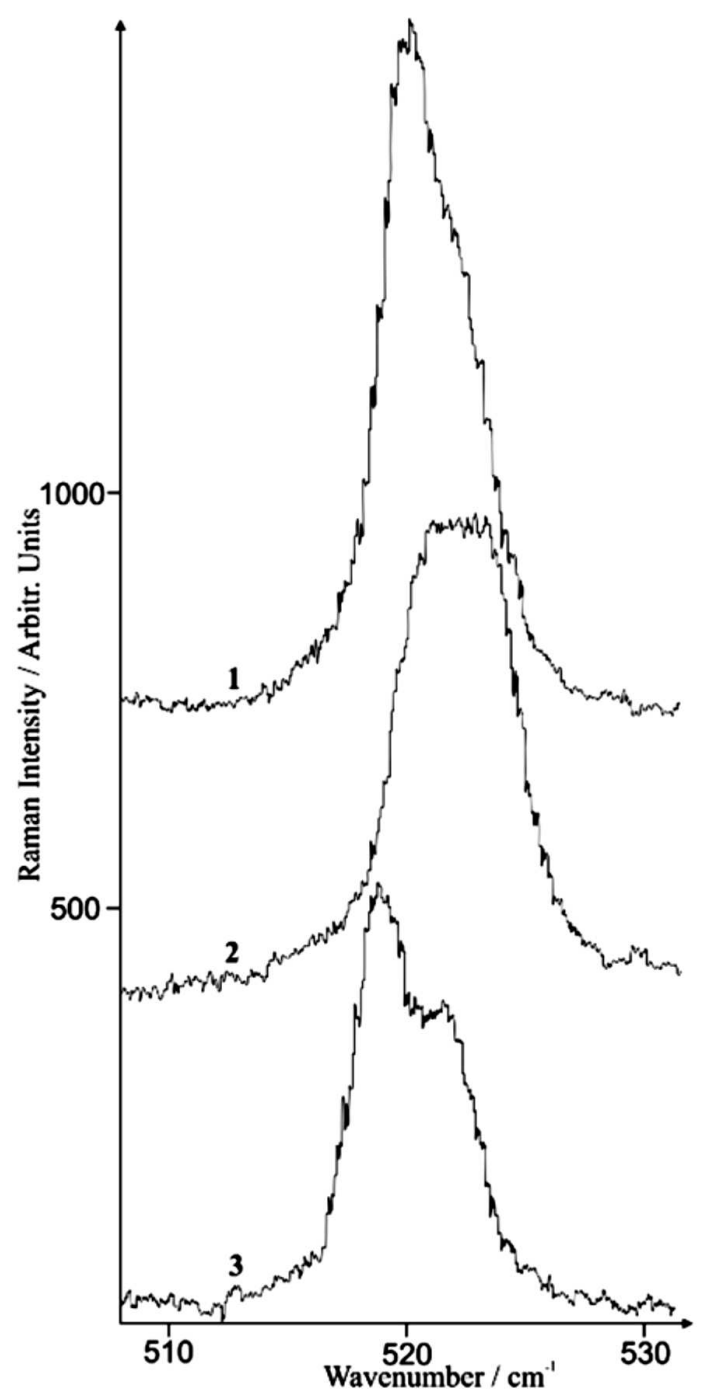

Fig. 1. $520 \mathrm{~cm}^{-1}$ bands of spectra of Raman scattering in quinoline: 1 - parallel polarized component, 2 - perpendicularly polarized component, 3 - solution of quinoline $(0.2 \mathrm{~m}$.f. $)$ with chloroform $(0.8$ m.f. $)$. Here and below, the intensities are not reduced to a unified scale

for a long time. The theoretical studies of the problem can be found in [37-46]. Our experimental data show that the interpretation of this phenomenon proposed in this paper cannot be neglected.

As was shown by our experiments, the resulting $520-$ $\mathrm{cm}^{-1}$ band is sensitive to intermolecular interactions. As in other cases [47], the dilution of quinoline by a large amount of a neutral solvent leads to a narrowing of the overlapping lines, and these lines can be resolved experimentally (Fig. 1). But, because of the complexity of the band, the interpretation of spectral changes of the band with changing interactions of molecules is difficult.

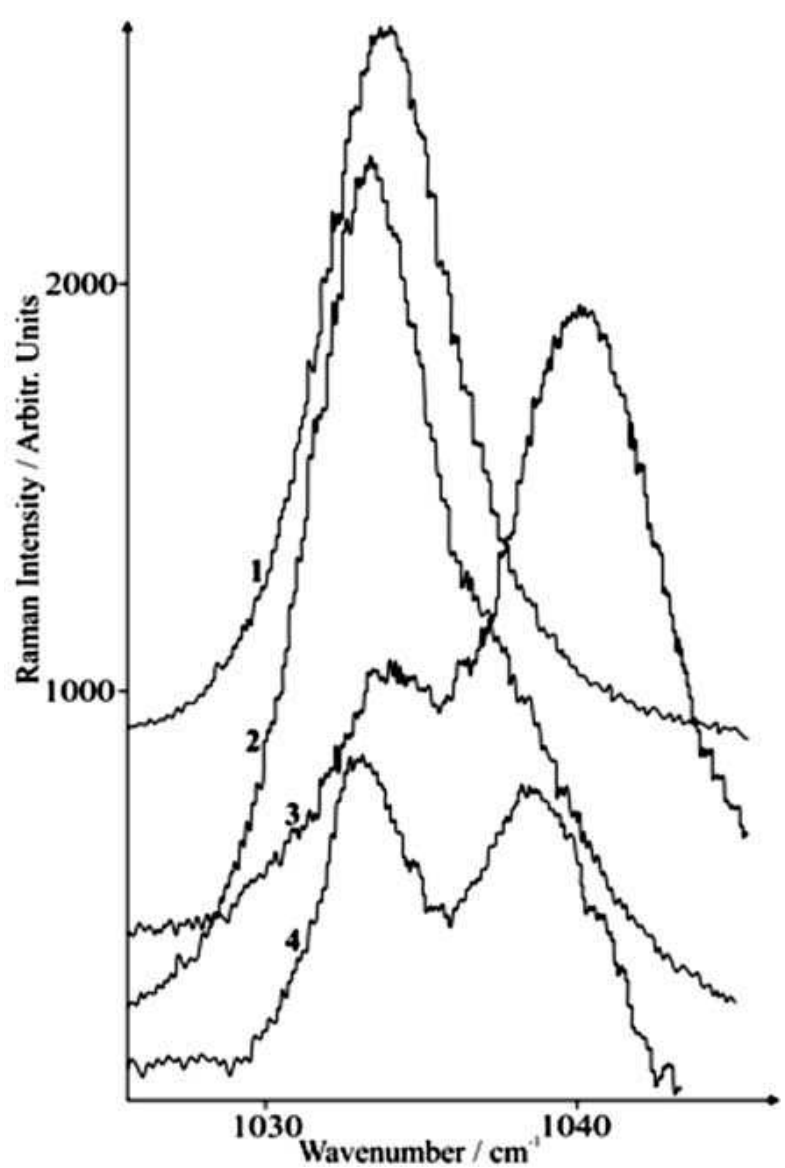

Fig. 2. 1034- $\mathrm{cm}^{-1}$ bands in pure liquid quinoline (1); in solution with propan-2-ol; 2, 3 concentration of quinoline, respectively, 0.8 m.f. and 0.15 m.f., and ternary mixture quinolin - propan-2-ol - benzene (concentration of components, respectively, 0.02 m.f., 0.20 m.f. and 0.78 m.f.)

Figure 2 shows the Raman spectra of quinoline and its solutions in the range of wave numbers 1000$1040 \mathrm{~cm}^{-1}$. In this region, we have two vibrational bands of quinoline, $1014.3 \mathrm{~cm}^{-1}$ and $1033.8 \mathrm{~cm}^{-1}$ (calculated wavenumbers are 1037.2 and $1054.4 \mathrm{~cm}^{-1}$ ). According to the calculations, the two bands correspond to planar vibrations of molecules and are not characteristic; moreover, in the first vibration, the nitrogen atom just slightly shifts from its equilibrium position. In the second vibration, the nitrogen atom together with other atoms is in a state of significant vibrational motion. The half-widths of the bands (without polarization decomposition) are, respectively, 4.0 and $5.1 \mathrm{~cm}^{-1}$. Both bands are sensitive to the dilution of quinoline in a neutral solvent, both bands become narrower (see Table).

The narrowing of the 1014.3- and 1033.8- $\mathrm{cm}^{-1}$ bands is apparently due to a large extent, like the case of the 
$520 \mathrm{~cm}^{-1}$ band, to a rise of the vibrational relaxation time. As it has been already said, such a rise is usually observed in the case of the dilution of substances in a neutral solvent. Another picture of the behavior of the $1033.8-\mathrm{cm}^{-1}$ band is observed for the solution of quinoline with propan-2-ol. Figure 2 shows the spectrum with the $1033.8-\mathrm{cm}^{-1}$ band of quinoline in the solution with propan-2-ol. As can be seen from the spectra in solution with propan-2-ol, the $1033.8-\mathrm{cm}^{-1}$ band undergoes a very significant change. The band has a clear doublet character with the difference in the peak frequencies of the bands to be $5.5 \mathrm{~cm}^{-1}$. The highfrequency component of the band increases by intensity (with respect to the low-frequency band) with the dilution with quinoline. Propan-2-ol is self-associated in the pure liquid, and its molecules easily form intermolecular hydrogen bonds with solvent molecules possessing proton-acceptor properties. The concentration dependence of the band shape shows that the newly appeared high-frequency band corresponds to quinoline--propan-2ol aggregates. Any complexity similar to that in the case of pyridine-propan-2-ol solutions [48] is not manifested for the $1040-\mathrm{cm}^{-1}$ band of aggregates. In [49], it was shown that the participation of molecules of propan-2-ol in the formation of $\mathrm{H}$-aggregates is evident not only in the band of $\mathrm{O}-\mathrm{H}$ vibrations, but also in the bands of vibrations of atoms, which are not directly involved in the formation of intermolecular hydrogen bonds. In particular, the $820-\mathrm{cm}^{-1}$ band of propan-2-ol involved in the formation of $\mathrm{H}$-bonds in the process of self-association or with proton-donor molecules is appeared to be of doublet character. Lines of the doublet band belong to different aggregates of alcohol. Judging by the results of this study, the doublet character of $820 \mathrm{~cm}^{-1}$ band of the alcohol occurs in solutions of the alcohol with quinoline. This can be judged by the concentration dependence of the $820-\mathrm{cm}^{-1}$ band. In the process of dilution of the alcohol, the band firstly is widened from $6.4 \mathrm{~cm}^{-1}$ in

Wavenumbers $(\nu)$ and half-widths $(\Delta \nu)$ of the 1014.3$\mathrm{cm}^{-1}$ and $1033.8-\mathrm{cm}^{-1}$ bands in solutions of quinoline with $\mathrm{CCl}_{4}$ and benzene

\begin{tabular}{c|c|c|c|c|c|c}
\hline $\begin{array}{c}\text { solution } \\
\text { quinoline, m.f. }\end{array}$ & \multicolumn{2}{|c|}{$\mathrm{CCl}_{4}$} & \multicolumn{2}{c|}{ benzene } & \multicolumn{2}{c}{$\mathrm{CCl}_{4}$} \\
\cline { 2 - 7 } & $\nu$ & $\Delta \nu$ & $\nu$ & $\Delta \nu$ & $\nu$ & $\Delta \nu$ \\
\hline 1.0 & 1014.3 & 4.0 & 1033.8 & 5.1 & 1033.8 & 5.1 \\
0.8 & 1013.8 & 3.2 & 1033.7 & 4.5 & 1033.5 & 4.3 \\
0.6 & 1013.4 & 3.2 & 1033.7 & 4.2 & 1033.5 & 4.2 \\
0.4 & 1013.8 & 2.9 & 1033.4 & 4.0 & 1033.3 & 3.8 \\
0.2 & 1013.8 & 2.7 & 1033.5 & 3.4 & 1033.2 & 3.7 \\
0.05 & 1014.0 & 2.7 & 1033.4 & 3.2 & - & - \\
\hline
\end{tabular}

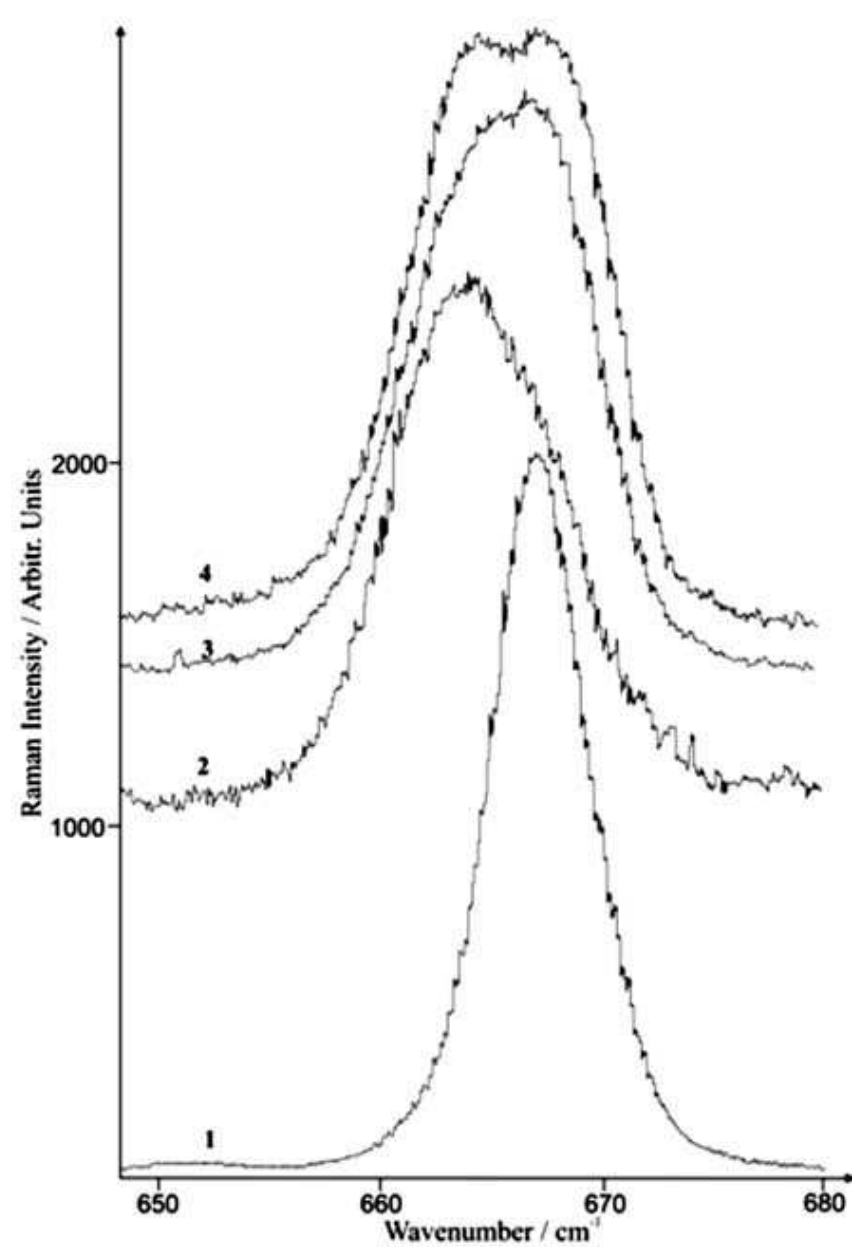

Fig. 3. Spectrum of Raman scattering of chloroform in solution with quinoline. 1 - pure chloroform; 2, 3- solution of chloroform (0.1 m.f.. and 0.5 m.f., respectively) with quinoline; $4-1 \mathrm{~cm}^{3}$ of the mixture of chloroform (0.31 m.f.) with quinoline $(0.69$ m.f. $)$ is diluted by $2 \mathrm{~cm} 3$ of heptane

pure alcohol up to $9 \mathrm{~cm}^{-1}$ in a solution with 0.1 m.f. of alcohol. At less concentrations, one should expect the narrowing of the line. The concentration dependence of the width of the $820-\mathrm{cm}^{-1}$ band of propan-2-ol is as follows: pure alcohol $-6.4 \mathrm{~cm}^{-1}(0.8 \mathrm{~m} . f$. of alcohol $)$, $6.9 \mathrm{~cm}^{-1}$ (0.6 m.f.), 7.4 (0.4 m.f.), 8.5 (0.2 m.f.), 9.0 (0.1 m.f.). We obtain some interesting results for solutions of quinoline in chloroform. As follows from our results, the $667-\mathrm{cm}^{-1}$ band of chloroform in a solution with the tert-butyl alcohol is split into two bands corresponding to monomeric molecules of chloroform (highfrequency line) and propan-2-ol-chloroform aggregates. A similar pattern is observed in our case of quinolinechloroform solutions. Figure 3 shows the spectrum of the $667-\mathrm{cm}^{-1}$ band of chloroform in a solution with quino- 
line. As one can see, at a high concentration of chloroform (0.8 m.f.), there appears an asymmetry in the low-frequency side. This asymmetry increases with the dilution of chloroform; the band is broadened. When the concentration of chloroform is 0.5 m.f., the asymmetry is significant. At $0.1 \mathrm{~m}$.f. of chloroform, the asymmetry moves to the region of higher frequencies. The shape of the band for the last two chloroform solutions is of non-monotonic character, which can be interpreted as a result of the overlapping of two bands with different intensities. In our opinion, these bands correspond to two types of molecules of chloroform: a monomer of chloroform (high-frequency band) and a chloroform-quinoline dimer (low-frequency band). As can be seen, despite the monotonic character and the change of the sign of asymmetry with varying concentration, there is no full confidence about the complexity of the $667-\mathrm{cm}^{-1}$ band. In this case, the method of ternary mixture [47] can be helpful. We diluted the double mixture of quinoline and chloroform by a large amount of heptane. Heptane is a neutral solvent with low density. In such a solvent, the bands of Raman scattering are usually narrowed, and the vibrational relaxation time increases. We expected that, in this ternary mixture, the lines of both monomers and aggregates of chloroform reduce their width, and the conditions for a resolution of the bands would become better. So it happened. Curve 4 in Figure 3 corresponds to the ternary mixture quinoline-chloroform-heptane. The doublet character of the band is evident. We should also note that the $520-\mathrm{cm}^{-1}$ bands of quinoline in the mixture with chloroform became resolvable as well (Fig. 1). Even at 0.2 m.f. of chloroform, the $520-\mathrm{cm}^{-1}$ band becomes non-monotonic in the high-frequency side. As the concentration of quinoline increases, this non-monotonic feature becomes clearer. At 0.4 m.f. of quinoline in the solution, the non-monotonic features appear in the $I_{\perp}(\nu)$ component. Note that the ratio of the intensity of bands is not noticeable with the further dilution. At $0.2 \mathrm{~m}$.f. of quinoline, two lines with wavenumbers of $518.2 \mathrm{~cm}^{-1}$ and $521.4 \mathrm{~cm}^{-1}$ are clearly manifested in the spectrum. Because of the complexity of the band, the interpretation of the observed picture for the $520-\mathrm{cm}^{-1}$ band is rather problematic even in the case of the pure liquid. Perhaps, this is a result of the improved resolution of bands due to reducing the width of the component lines (chloroform is a weak proton-donor, but the dilution of quinolone should lead to a decrease in the interaction of identical molecules, while the vibrational relaxation time should increase, and the line width should be reduced). In conclusion, we note the behavior of the 761$\mathrm{cm}^{-1}$ band of quinoline in neutral solvents and in a so- lution with chloroform. This band is also sensitive to the intermolecular interaction, but the interpretation of experimental results is complicated by the presence of the low-frequency side in the wing of the band of a lowintense line, which is present in the pure liquid and in solutions with neutral and active solvents. The influence of this line on the $761-\mathrm{cm}^{-1}$ band is not significant, especially in terms of the half-width. The half-width of the $761-\mathrm{cm}^{-1}$ band behaves as follows. In neutral solvents (benzene, chlorobenzene), the width of the band, as well as the width of the 1014.3- and $1033.8-\mathrm{cm}^{-1}$ bands, decreases (identically both for benzene and chlorobenzene) from 3.7 to $2.4 \mathrm{~cm}^{-1}$. In a solution with chloroform with the dilution with quinoline, the $761-\mathrm{cm}^{-1}$ band passes through a maximum: its width firstly increases from 3.7 to $5.2 \mathrm{~cm}^{-1}$ (at $0.5 \mathrm{~m}$.f. quinoline) and then decreases to $4.3 \mathrm{~cm}^{-1}$ (at $0.2 \mathrm{~m}$.f. of quinoline). Figure 4 shows the calculated structure of monomers of quinoline and isopropyl alcohol, and propan-2-ol - quinoline aggregate. It is evident that there is the hydrogen bond between the molecules involving the hydrogen of $\mathrm{OH}$ group of the alcohol and the nitrogen atom of quinoline. The length of the hydrogen bond is $1.958 \AA$. We also note that a quite intense interaction takes place between the oxygen atom $\mathrm{O}^{19}$ of the alcohol and one of the hydrogen atoms of quinoline $\mathrm{H}^{13}$ (atom numbers are the same as in the figure). The distance $\mathrm{O}^{19}-\mathrm{H}^{13}$ is $2.627 \AA$. The overall energy gain during the formation of such aggregate is $22.0 \mathrm{~kJ} / \mathrm{mole}$. The figure shows that the formation of aggregates is accompanied by changes in the lengths of some bonds and the charge redistribution between the atoms for both molecules. In full accordance with experiment, the calculated frequency of the $1037-\mathrm{cm}^{-1}$ band (experimental value is $1033.8 \mathrm{~cm}^{-1}$ ) of monomers shifts to higher frequencies in the process of formation of $\mathrm{H}-$ aggregates $\left(\sim 7 \mathrm{~cm}^{-1}\right)$.

\section{Conclusions}

1. Non-coincidence of peak frequencies of bands in spectra of Raman scattering of different polarizations is connected with the complexity of these bands - the presence of two lines within a band, which are slightly different with respect to the peak frequency and possess different depolarization ratios. These lines are not resolved by experimental apparatus. But, because of the presence of the isotropic and anisotropic components, the intensity of the isotropic component of one line dominates for one polarization of the scattered light, while, for the other polarization, the anisotropic component of the other line is predominant, which leads 

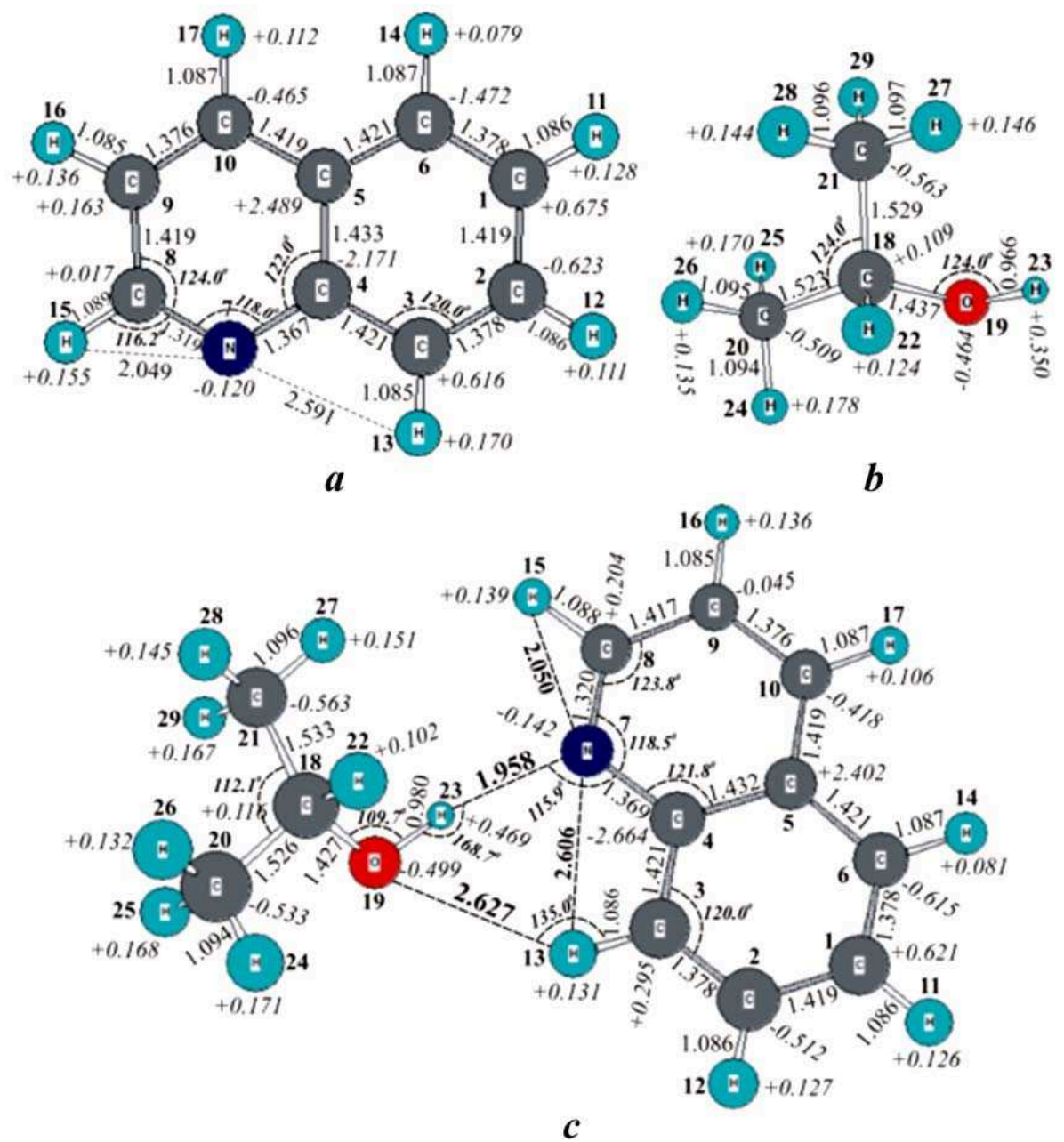

Fig. 4. Structure of monomeric molecules of quinoline $(a)$ and propan-2-ol (b), as well as quinoline - propan-2-ol aggregates (c) (distance is in $\AA$, charges are in units of electron's charge)

to the non-coincidence of peak frequencies of complicated bands for different polarizations of the scattered light.

2. Just as in other nitrogen-containing compounds, the formation of intermolecular hydrogen bonds between the molecules of quinoline leads to the appearance of the bands of aggregates in the high-frequency part of vibrations involving the nitrogen atom that is connected with the strengthening of bonds of electrons in the closed ring of a quinoline molecule.

3. The method of strong dilution of the substance in a neutral solvent is found to be effective in the case of quinoline solutions. As a result of the strong narrowing of the bands in these solvents, the complicated bands in the spectra of Raman scattering become resolvable. The strong decrease in the width of the bands in neutral solvents is connected with the destruction of aggre- gates in liquid media and with increase of the lifetime of molecules in a given vibrational state.

1. G.A. Jeffrey and W. Saenger, Hydrogen Bonding in Biological Structures (Springer, Berlin, 1991).

2. G.C. Pimentel and A.L. McClellan, The Hydrogen Bond (Freeman, San Francisco, 1960).

3. C.L. Perrin and J.B. Nielson, Annu. Rev. Phys. Chem. 48, 511 (1997).

4. X. Wu, Y. Chen, and T. Yamaguchi, J. Mol. Spectr. 246, 187 (2007).

5. T. Scharge, D. Luckhaus, M. A. Suhm, Chem. Phys. 346, 167 (2008).

6. K. Suhara, A. Fujii, K. Mizuse, and N. Mikami, J. Chem. Phys. 126, 194306 (2007).

7. R. Wugt Larsen, P. Zielke, and M.A. Suhm, J. Chem. Phys. 126, 94307 (2007). 
8. L. Zoranic, F. Sokolic, and A. Perera, J. Chem. Phys. 127, 024502 (2007).

9. E.F. Fileti, M. Castro, and S. Canuto, Chem. Phys. Lett. 452, 54 (2008); 127, 024502 (2007).

10. E.I. Doroshenko, O. Lizengevych, V. Pogorelov, and L. Savransky, Ukr. J. Phys. 49, 540 (2004).

11. S. Boyd and R. Boyd, J. Chem. Theory Comput. 3, 54 (2007).

12. T.N. Wassermann, P. Zielke, J.J. ee, C. Cezard, and M.A. Suhm, J. Phys. Chem. A 111, 7437 (2007).

13. Y. Liu, S. Consta, F. Ogeer, Y.J. Shi, and R.H. Lipson, Can. J. Chem. 85, 843 (2007).

14. C.Cezard, C.A.Rice, M.A.Suhm. J. Phys. Chem. A, 110, 9839 (2006).

15. F.H. Tukhvatullin, V.E. Pogorelov, A. Jumabaev, H.A. Hushvaktov, A.A. Absanov, and A. Shaymanov, J. Mol. Struct. 881, 52 (2008).

16. Y. Tamenori, K. Okada, O. Takahashi, S. Arakawa, K. Tabayashi, A. Hiraya, T. Gejo, and K. Honma, J. Chem. Phys. 128, 124321 (2008).

17. G.-J. Zhao and K.-L. Han, J. Phys. Chem. A 111, 2469 (2007).

18. G.-J. Zhao, J.-Y. Liu, L.-C. Zhou, and K.-L. Han, J. Phys. Chem. B 111, 8940 (2007).

19. G.-J. Zhao and K.-L.Han, Biophys. J. 94, 1, 38 (2008).

20. F.H. Tukhvatullin, V.Ye. Pogorelov, A. Jumabaev, H.A. Hushvaktov, A.A. Absanov, and A. Usarov, J. Mol. Liq. 160, 88 (2011).

21. V. Pogorelov, L. Bulavin, I. Doroshenko, O. Fesjun, and O. Veretennikov, J. Mol. Struct. 708, 61 (2004).

22. V. Pogorelov, A. Yevglevsky, I. Doroshenko, L. Berezovchuk, and Yu. Zhovtobryuch, Superlatt. Microstr. 4, 571 (2008).

23. I.Yu. Doroshenko, A.I. Lizengevych, V.E. Pogorelov, and L.I. Savransky, Visn. Kiev. Univ. Ser. Fiz. Mat. Nauky 8-9, 19 (2008).

24. V. Pogorelov, I. Doroshenko, P. Uvdal, V. Balevicius, and S. Sablinskas, Mol. Phys. 108, 2165 (2010).

25. S. Schlund, M. Mladenovic, E.M. Basilio Janke, B. Engels, and K. Weisz, J. Am. Chem. Soc. 127, 16151 (2005).

26. H.S. Andrei, N. Solca, and O. Dopfer, Chem. Phys. Chem. 7, 107 (2006).

27. D.K. Singh, S.K. Srivastava, S. Schlucker, R.K. Singh, and B.P. Asthana, J. Raman Spectrosc. 42, 851 (2011).

28. V. Deckret, B.P. Asthana, P.C. Mishra, and W. Kiefer, J. Raman Spectrosc. 27, 907 (1996).

29. R.K. Singh, S.K. Srivastava, A.K. Ojha, U. Arvind, and B.P. Asthana, J. Raman Spectrosc., 37, 76 (2006).

30. A.K. Ojha, S.K. Srivastava, S. Schlucker, W. Kiefer, B.P. Asthana, and R.K. Singh, J. Raman Spectrosc. 38, 1656 (2007).
31. F.H. Tukhvatullin, A. Jumabaev, G. Muradov, H.A. Hushvaktov, and A.A. Absanov, J. Raman spectrosc. 10, 932 (2005).

32. M. Bolboaca, W. Kiefer, and J. Popp, J. Raman Spectrosc. 33, 207 (2002).

33. P. Sett, M. Ghosh, P.K. Mallick, and J. Chowdhury, J. Raman Spectrosc. 39, 1878 (2008).

34. M. Balyn, P. Guardado, M.A. Mucoz, and C. Carmona, Biospectr. 4, Issue 3, 185 (1998).

35. K. Tanabe and J. Hiraichi, Spectrochim. Acta. A36, 341 (1980).

36. M.J. Frisch, G.W. Trucks, H.B. Schlegel, G.E. Scuseria, M.A. Robb, J.R. Cheeseman, V.G. Zakrzewski, J.A. Montgomery, Jr., R.E. Stratmann, J.C. Burant, S. Dapprich, J.M. Millam, A.D. Daniels, K.N. Kudin, M.C. Strain, O. Farkas, J. Tomasi, V. Barone, M. Cossi, R. Cammi, B. Mennucci, C. Pomelli, C. Adamo, S. Clifford, J. Ochterski, G.A. Petersson, P.Y. Ayala, Q. Cui, K. Morokuma, D. K. Malick, A.D. Rabuck, K. Raghavachari, J.B. Foresman, J. Cioslowski, J.V. Ortiz, B.B. Stefanov, G. Liu, A. Liashenko, P. Piskorz, I. Komaromi, R. Gomperts, R.L. Martin, D.J. Fox, T. Keith, M.A. Al-Laham, C.Y. Peng, A. Nanayakkara, C. Gonzalez, M. Challacombe, P.M.W. Gill, B. Johnson, W. Chen, M.W. Wong, J.L. Andres, C. Gonzalez, M. Head-Gordon, E.S. Replogle, and J.A. Pople, Gaussian 98, Revision A.3, (Gaussian, Pittsburgh, 1998).

37. V.I. Korsunskiy, N.L. Lavrik, and Y.I. Naberukhin, Zh. Opt. Spektrosk. 41, 794, (1976).

38. C. Perchard and J.P. Perchard, Chem. Phys. Lett. 27, 445 (1974).

39. G. Fini and P. Mirone, J. Chem. Soc. Faraday Trans. 2. 70, 1776 (1974).

40. P. Mirone and G. Fini, J. Chem. Phys. 71, 2241 (1979).

41. G. Fini and P. Mirone, Spectrochim. Acta Part. A 32, 625 (1976).

42. C. Perchard and J.P. Perchard, J. Raman Spectrosc. 3, 277 (1975).

43. C. Perchard and J.P. Perchard, J. Raman Spectrosc. 6, 74 (1975).

44. M. Schwarz and C.H. Wang, Chem. Phys. Lett. 25, 26 (1974).

45. D.R. Jones, C.H. Wang, D.H. Christensen, and O.F. Nielson, J. Chem. Phys. 64, 4475 (1976).

46. R.J. Bartholomew and D.E. Irish, J. Raman Spectrosc. 29, 115 (1998).

47. A.K. Atakhodjaev, F.H. Tukhvatullin, A. Jumabayev, and U.N. Tashkenbaev, JETP Letters 51, 509 (1990).

48. F.H. Tukhvatullin, B.G. Hudayberdiev, A. Jumabaev, H.A. Hushvaktov, and A. Absanov, J. Molec. Liquid 155, 67 (2010). 
49. F.H. Tukhvatullin, A. Jumabaev, H. Hushvaktov, A. Absanov, and A. Shaymanov, J. Raman Spectrosc. 38, 1633 (2007).

Received 14.10.11

\section{РАМАНІВСЬКІ СПЕКТРИ І МІЖМОЛЕКУЛЯРНІ ВОДНЕВІ ЗВ'ЯЗКИ ХІНОЛІНУ У РОЗЧИНАХ}

Ф.Х. Тухватуллін, А. Джумабаєв, Х. Хуштактов, А. Абсанов, Б. Худойбердієв

$\mathrm{P}$ е $з$ ю м е

Півширини смуг при 1014 і $1033 \mathrm{~cm}^{-1}$ у раманівському спектрі хіноліну зменшуються в 1,3-1,5 раза при сильному розбавленні нейтральними розчинниками (бензол $\mathrm{CCl}_{4}$ ). Цей ефект зумовлений збільшенням часу коливальної релаксації. Для смуги при $520 \mathrm{~cm}^{-1}$ у чистому рідкому хіноліні, паралельно поляризована компонента асиметрична при $20{ }^{\circ} \mathrm{C}$ в області високих частот. Перпендикулярно поляризована компонента має складну форму. Спостерігається різниця у частотах піків цих компонент $\left(\sim 2 \mathrm{~cm}^{-1}\right)$. Квантово-хімічні розрахунки показали, що в області $520 \mathrm{~cm}^{-1}$ для молекули мономеру наявні дві близькі лінії з хвильовими векторами 530 і 527 см$^{-1}$ (коефіцієнт подібності дорівнює 0,97) і з коефіцієнтом деполяризації 0,61 і 0,26. У розчинах з пропан-2-олом смуга при 1033,8 см$^{-1}$ стає дублетом. Розрізнення дублета поліпшується при розбавленні бінарного хінолін-спирт розчину великою кількістю нейтрального розчинника (бензол). Хвильові вектори смуг у потрійній суміші дорівнюють $1033 \mathrm{~cm}^{-1}$ і $1039 \mathrm{~cm}^{-1}$. Дублетна природа смуги у бінарних і потрійних смугах пов'язана з присутністю молекул мономеру і асоціатів хінолін-пропан-2-ол (високочастотна лінія) у рідкій суміші. Квантово-хімічні розрахунки показали, що водневі зв'язки з довжиною $1,958 \AA$ і виграшем в енергії 22,0 кДж/моль можуть бути утворені між молекулами хіноліну і спирту. Утворення асоціатів може бути також виявлено за допомогою полоси $820 \mathrm{~cm}^{-1}$ пропан-2-ола. Подібна ситуація спостерігається для смуги хлороформу при $667 \mathrm{~cm}^{-1}$ при його розбавленні хіноліном. 